\title{
Chemopreventive properties of young green barley extracts in in vitro model of colon cancer
}

\author{
Katarzyna Kawka ${ }^{1, B-D, F \oplus}$, Marta Kinga Lemieszek ${ }^{1, A-F}{ }^{\oplus}$, Wojciech Rzeski ${ }^{1,2, A, E-F \oplus}$ \\ ${ }^{1}$ Department of Medical Biology, Institute of Rural Health, Lublin, Poland \\ ${ }^{2}$ Department of Virology and Immunology, Institute of Microbiology and Biotechnology, Maria Curie-Sklodowska \\ University, Lublin, Poland \\ A - Research concept and design, B - Collection and/or assembly of data, C - Data analysis and interpretation, \\ $D$ - Writing the article, E - Critical revision of the article, F - Final approval of article
}

Kawka K, Lemieszek MK, Rzeski W. Chemopreventive properties of young green barley extracts in in vitro model of colon cancer. Ann Agric Environ Med. 2019; 26(1): 174-181. doi: 10.26444/aaem/102624

\begin{abstract}
Introduction and objective. Young green barley is the most valuable source of nutrients and bioactive substances. It has a broad spectrum of health-promoting properties such as antioxidant, anti-inflammatory, hypoglycaemic, anti-depressant, anti-atherosclerotic and anticancer. The presented study is an attempt to extend this knowledge with particular emphasis on the possibility of using green barley in colon cancer prevention.

Materials and method. Extracts were prepared on the basis of two commercial products: ground dried barley grass (YGB INT) and powder of young green barley juice (YGB GW). Their influence on colon epithelial cells (CCD841 CoN) viability and proliferation were analyzed by LDH and MTT assays. Anticancer properties of extracts were screened on colon cancer cell lines (LS180, HT-29) by MTT and BrdU assays. Changes in cells morphology induced by extracts were investigated after May-Grünwald-Giemsa staining.

Results. Tested extracts were not toxic against CCD841 CoN and did not affected their proliferation or morphology (LDH test, MTT test, microscopy observation). The MTT revealed that extracts significantly inhibited proliferation of colon cancer cells in a dose-dependent manner. Results of BrdU test confirmed antiproliferative properties of extracts, but opposite to MTT test, indicated YGB GW as a better anticancer agent. Light microscopy observation proved the data obtained from both MTT and BrdU tests and additionally suggested the ability of the extracts to induce necrosis in LS180 and HT-29 cells. Conclusions. The study demonstrated that YGB extracts specifically inhibit proliferation of colon cancer cells without any undesirable effect on colon epithelial cells. Obtained results will provide a rationele for the future development of dietary supplements which could be beneficial in colon cancer chemoprevention.
\end{abstract}

Key words

Hordeum vulgare, barley, colon cancer, chemoprevention

\section{INTRODUCTION}

Barley (Hordeum vulgare L.) is one of the first plants cultivated by humans. The domestication of this cereal took place in the Middle East about 10,000 years ago [1]. Barley yield is around $30 \%$ of the total worldwide cereal production. [2]. It is estimated that about $75 \%$ of the barley crop is destined for feeding animals, $20 \%$ is used in the production of alcoholic or non-alcoholic beverages, and other $5 \%$ is the food additive [3]. Barley is grown in many unfavourable areas thanks to its superior adaptability to diverse conditions and high resistance to environmental stress caused by climate changes [1]. These unique features, as well as low costs of cultivation, have made barley a paramount source of food in many countries and some areas of North Africa, the Middle East and the mountains of Central Asia [4].

Kazuhiko Kubota's studies have shown that young green barley is the most valuable source of nutrients and bioactive substances. The young green barley is defined as seedlings up to 200 hours from germination, with a height between $20-30 \mathrm{~cm}[5,6]$. Barley (grains and grass) contains significant amounts of amino acids, vitamins, minerals and trace

Address for correspondence: Marta Kinga Lemieszek, Department of Medical Biology, Institute of Rural Health, Lublin, Poland

e-mail: lemieszek.marta@imw.lublin.pl

Received: 21.06.2018; accepted: 03.01.2019; first published: 13.02.2019 elements, insoluble and soluble dietary fibre, antioxidants and other bioactive substances, such as superoxide dismutase, catalase, 2-O-glycosyl isovitexin, peroxydase, carotenoids and chlorophyll $[7,8,9,10,11]$. Numerous studies have shown that the total content of nutrients and bioactive substances in young barley depends on the locus, soil type, rainfall, harvesting technology and plant age [11]. It was proved that the contents of vitamin C, polyphenols, phenolic compounds (ferulic acid), as well as amino acids, glucose and fructose, was inversely proportional to the age of the plant [9]. But not only the age of the plant affects on the amount of nutritious substances, the commercial form of barley is also important. Juice squeezed from barley leaves are a better source of easily digestible nutrients and/or bioactive substances than raw barley grass. Dehydrated juice has no moisture, the nutrients are intact and not broken down. As a result, the nutrients are retained in an excellent, assimilable food product which keeps well and is resistant to spoilage. [10].

Furthermore, young green barley has a broad spectrum of health-promoting properties, such as antioxidant $[8,9$, $10,12]$, anti-inflammatory $[10,13]$, anti-depressant [14], hypoglycemic $[15,16]$ and anti-atherosclerotic $[17,18,19$, 20]. Barley seedlings also may inhibit differentiation of osteoclasts and bone-resorbing activity in all the stages of osteoclastogenesis [21]. In that case, supplementation of green barley should be favourable for health and may 
prevent diseases caused by oxidative damage, such as neurodegenerative and cardiovascular diseases or various cancers [22].

The presented study investigates and compares the chemopreventive potential of young green barley extracts prepared on the basis of two different commercial products (ground dried barley grass from Intenson and powdered young green barley juice from Green Ways). Antiproliferative activity of the studied extracts was tested in human colon cancer cells. Furthermore, the impact of the extracts on viability and morphology colon epithelial cells in humans was also investigated.

\section{MATERIALS AND METHOD}

Reagents. Unless otherwise indicated, the chemicals used in the study were purchased from Sigma-Aldrich Co. LLC

Preparation of young barley extracts. 1) Ground barley grass meal (INTENSON, Całowanie 94G, 05-480 Karczew) was purchased in a local market. $2.5 \mathrm{~g}$ of grass powder were suspended in $100 \mathrm{ml}$ of pure sterile water and extracted on a magnetic stirrer for $24 \mathrm{~h}\left(20^{\circ} \mathrm{C}\right)$. After this time, the solution was centrifuged $\left(10 \mathrm{~min}, 4075 \mathrm{x} \mathrm{g}, 20^{\circ} \mathrm{C}\right)$, filtered, and vacuum evaporated (vacuum rotary evaporator type 350 , UNIPAN, Warsaw, Poland). Stock solution (100 mg/ml) was prepared by dissolving the crystallized form of the barley in PBS (phosphate-buffered saline). In the current study, this extract was designated YGB INT.

2) Powdered juice from young barley leaves (GREEN WAYS, Ovocný trh 572/11, 11000 Prague 1, Czech Republic) was obtained from a distributor. 3.3 grams of powder were suspended in $100 \mathrm{ml}$ of PBS and extracted on a magnetic stirrer for $24 \mathrm{~h}$ at $20^{\circ} \mathrm{C}$. The solution was then centrifuged (10 $\mathrm{min}, 4075 \mathrm{x} \mathrm{g}, 20^{\circ} \mathrm{C}$ ). The obtained supernatant was filtered in sterile conditions, while precipitate was collected, dried and weighed in order to assess the amount of substance that actually went into solution during the extraction. The precipitate weighed 1.218 grams and the resulting extract which contained 2.082 grams of substance was stock solution (100\%; 21 mg/ml). This extract was designated YGB GW.

Nutritional values of young barley commercial products used for the preparation of the studied extracts is shown in Table 1. Comparison of young barley extracts preparation is shown in Figure 1.

Stock solutions of YGB INT and YGB GW extracts were stored at $4^{\circ} \mathrm{C}$. Stock solutions were prepared once and used in all described experiments. The duration of the study from the beginning to the end was 6 months. During this period, no disturbing changes were observed in the stock solutions, i.e. precipitation, colour change, or development of microorganisms (microscopic observations). Stability of biological activity of the extracts was vitrificated by MTT test in LS180 cells at the end of study, as described below. Changes between results of MTT test carried out at an interval of 6 months were not statistically significant. Working solutions of both extracts were prepared immediately before use by dissolving an appropriate stock solution in a culture medium. Studies were conducted using YGB INT at concentrations: 25, 50, 75, 100, $250 \mu \mathrm{g} / \mathrm{ml}$, and YGB GW at concentrations: $16,32,63,158,315,630,1050,1575,2100 \mu \mathrm{g} / \mathrm{ml}$.
Table 1. Nutritional values of young barley commercial products used for the preparation of YGB INT and YGB GW extracts. Nourishing value was given per $100 \mathrm{~g}$ dry weight of the product. Prepared based on the manufacturer's information

\begin{tabular}{lcc}
\hline & $\begin{array}{c}\text { Intenson ground } \\
\text { dried barley grass }\end{array}$ & $\begin{array}{c}\text { Green Ways powdered } \\
\text { young green barley juice }\end{array}$ \\
\hline Energy & $1143 \mathrm{~kJ} / 275 \mathrm{kcal}$ & $1340 \mathrm{~kJ} / 319 \mathrm{kcal}$ \\
\hline Fats, of which: & $3.2 \mathrm{~g}$ & $3.9 \mathrm{~g}$ \\
\hline saturated fatty acids & $0.7 \mathrm{~g}$ & $1.1 \mathrm{~g}$ \\
\hline monounsaturated fatty acids & not specified & $0.2 \mathrm{~g}$ \\
\hline polyunsaturated fatty acids & not specified & $2.6 \mathrm{~g}$ \\
\hline Carbohydrates, of which: & $16 \mathrm{~g}$ & $39 \mathrm{~g}$ \\
sugars & $11 \mathrm{~g}$ & $23 \mathrm{~g}$ \\
\hline Fiber & $44 \mathrm{~g}$ & $6.9 \mathrm{~g}$ \\
\hline Protein & $24 \mathrm{~g}$ & $28 \mathrm{~g}$ \\
\hline Salt & $0.3 \mathrm{~g}$ & $2.9 \mathrm{~g}$ \\
\hline
\end{tabular}

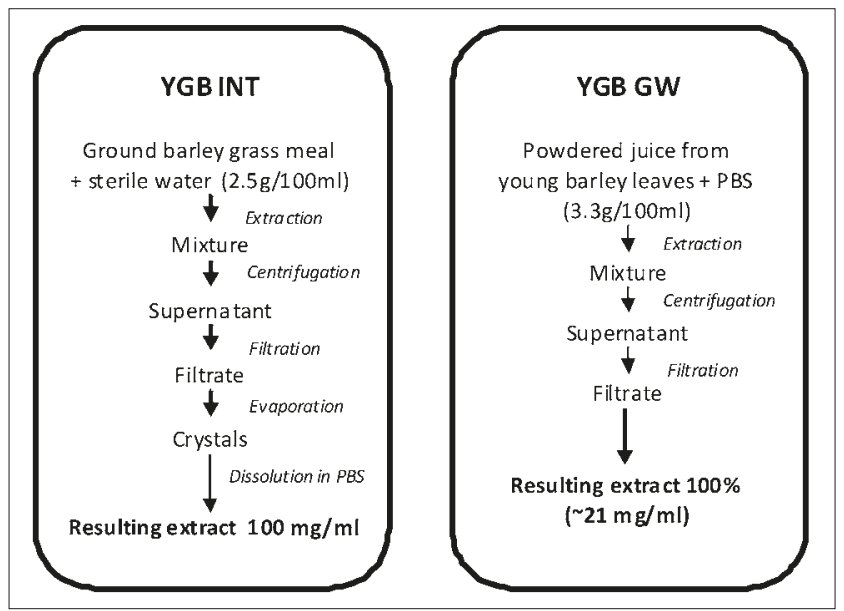

Figure 1. Differences in preparation of young green barley (YGB) extracts YGB INT - extract of young green barley prepared on the basis of a product from Intenson.

YGB GW - extract of young green barley prepared on the basis of a product from Green Ways.

Cell lines. The human colon adenocarcinoma cell lines LS180 and HT-29 were obtained from ECACC (European Collection of Cell Cultures, Center for Applied Microbiology and Research, Salisbury, UK). The human colon epithelial cell line CCD $841 \mathrm{CoN}$ was purchased from the ATCC (American Type Culture Collection, Menassas, VA, USA).

The LS180 and HT-29 cells were grown in a mixture of Dulbecco's Modified Eagle's Medium (DMEM) and nutrient mixture F-12 Ham (1:1). The CCD 841 CoN cells were cultured in Eagle's Minimum Essential Medium (EMEM). All media were supplemented with $10 \%$ FBS (foetal bovine serum), 100 units $/ \mathrm{ml}$ penicillin and $100 \mu \mathrm{g} / \mathrm{ml}$ streptomycin. Cells were maintained in a humidified atmosphere of $95 \%$ air and $5 \% \mathrm{CO} 2$ at $37^{\circ} \mathrm{C}$.

Studies were conducted in cell lines derived from female donors in order bypass the gender-specific differences [23, 24].

LDH assay - extract cytotoxicity assessment. CCD 841 CoN cells were plated on 96-well microplates at a density of $1 \times 10^{5}$ cells $/ \mathrm{ml}$. On the following day, the growth medium was removed and the cells were exposed to a series of tested extracts dilutions. The extracts solutions were prepared in a medium containing 2\% FBS. After 24 hours of exposure, 
the culture supernatants were collected and transferred to new 96-well plates which were used to execute the LDH assay, according to the manufacturer's instructions (In vitro Toxicology Assay Kit, Lactate Dehydrogenase Based). Absorbance was recorded on a microplate reader (BioTek ELx800, Highland Park, Winooski, Vermont, USA) at $450 \mathrm{~nm}$ wavelength. The findings were presented as a percentage of $\mathrm{LDH}$ released from the cells treated with barley extracts versus cells grown in the control medium (indicated as 100\%).

MTT assay - cell viability/proliferation assessment. CCD 841 CoN, LS180 and HT-29 cells were plated on 96-well microplates at a density of $3 \times 10^{4}$ cells $/ \mathrm{ml}$. The following day, the growth medium was replaced by a fresh one, and the cells were exposed to series of dilutions of tested extracts (YGB INT $25-250 \mu \mathrm{g} / \mathrm{ml}$; YGB GW $16-2100 \mu \mathrm{g} / \mathrm{ml}$ ) prepared in a medium containing $10 \%$ FBS. After 96 hours of incubation, the cells were incubated with MTT solution $(5 \mathrm{mg} / \mathrm{ml})$ for $3 \mathrm{~h}$. Formazan crystals were solubilized overnight in SDS buffer $\mathrm{pH} 7.4(10 \% \mathrm{SDS}$ in $0.01 \mathrm{~N} \mathrm{HCl})$. After this time, the colour product was quantified spectrophotometrically by measuring the absorbance at $570 \mathrm{~nm}$ wavelength using a microplate reader (BioTek ELx800). Cell proliferation (\%) was expressed as a percentage relative to the untreated control cells.

BrdU assay - cell proliferation assessment. LS180 and HT-29 cells were plated on 96-well microplates at a density of $5 \times 10^{4}$ cells $/ \mathrm{ml}$. The next day, the growth medium was replaced by a fresh one and the cells exposed to series of dilutions of tested extracts (YGB INT 25-250 $\mu \mathrm{g} / \mathrm{ml}$; YGB GW $16-2100 \mu \mathrm{g} / \mathrm{ml}$ ) prepared in the medium supplemented with $10 \%$ FBS. Cell proliferation was quantified after 48 hours of treatment, according to the manufacturer's instructions, Cell Proliferation ELISA BrdU (Roche Diagnostics GmbH, Penzberg, Germany). The absorbance was measured at $450 \mathrm{~nm}$ wavelength using a microplate reader (BioTek ELx800). The influence of the barley extracts on DNA synthesis was presented as a percentage of BrdU incorporation versus control cells (indicated as 100\%).

Morphological examination. To assess changes in cell morphology, May-Grünwald-Giemsa staining was used. Cells were plated on Lab-Tek Chambers Slide (Nunc) at a density of $0.5 \times 10^{5}$ cells $/ \mathrm{mL}$. Next day, the culture medium was removed and the cells were exposed to serial dilutions of the tested extracts (YGB INT 50, 10, $250 \mu \mathrm{g} / \mathrm{ml}$; YGB GW $58,1050,2100 \mu \mathrm{g} / \mathrm{ml})$ in culture medium supplemented with $10 \%$ FBS. After 48 hours, the cells were stained by the MayGrünwald-Giemsa method. The stained cells were observed by light microscope (Olympus BX51 System Microscope, Olympus Optical Co., Japan).

Statistical analysis. The data were presented as the mean value and standard error of the mean (SEM). The data were analyzed by one-way ANOVA test, Tukey's Multiple Comparison Post-test. Significance was accepted at $\mathrm{p}<0.05$. The $\mathrm{IC}_{50}$ value (concentration causing proliferation inhibition by $50 \%$, compared to control) was calculated according to the method of Litchfield and Wilcoxon [25].

\section{RESULTS}

Influence of barley extracts on human colon epithelial cells viability and proliferation. The cytotoxicity of the extracts and impact on the proliferation of human colon epithelial cells (CCD $841 \mathrm{CoN}$ ) were examined by LDH and MTT tests after 24 hours and 96 hours of cells treatment, respectively. The study showed that YGB INT and YGB GW extracts were not toxic against human colon epithelial cells in the whole range of analyzed concentrations. Furthermore, YGB INT at concentration $100 \mu \mathrm{g} / \mathrm{ml}$ significantly reduced LDH release from the treated cells (Fig. 2, upper panel). Results of MTT assay showed that the investigated extracts did not affect colon epithelial cells proliferation in the whole range of tested concentrations (Fig. 2, lower panel).

Antiproliferative effect of barley extracts on human colon cancer cells. The antiproliferative effect of barley extracts was assessed on human colon adenocarcinoma cell lines LS180 and HT-29 by MTT and BrdU tests after 96 hours and 48 hours of cells treatment, respectively.

MTT test revealed that YGB INT and YGB GW extracts inhibited proliferation of colon cancer cells; nevertheless, only YGB GW induced changes in dose-dependent manner (Fig. 3). YGB INT extract elicited a more significant antiproliferative effect compared to YGB GW, in both cell lines. YGB INT at the highest tested concentration $250 \mu \mathrm{g} / \mathrm{ml}$ decreased cell proliferation to $23.7 \%$ in LS180 and $43.9 \%$ in HT-29, while YGB GW induced a similar effect at a concentration of around $2,100 \mu \mathrm{g} / \mathrm{ml}$ (LS180) and $630 \mu \mathrm{g} / \mathrm{ml}$ (HT-29). The $\mathrm{IC}_{50}$ value was as follow: $62 \mu \mathrm{g} / \mathrm{ml}$ (YGB INT; LS180), $144 \mu \mathrm{g} / \mathrm{ml}$ (YGB INT; HT-29), $1239 \mu \mathrm{g} / \mathrm{ml}$ (YGB GW; LS180), $294 \mu \mathrm{g} / \mathrm{ml}$ (YGB GW; HT-29).

In a more specific antiproliferative test, BrdU showed that both extracts inhibited DNA synthesis in treated colon cancer cells (Fig. 4). The YGB INT reduced proliferation of the LS180 cells in a dose dependent manner. YGB INT at $250 \mu \mathrm{g} / \mathrm{ml}$ decreased BrdU incorporation in the treated cells by $22.9 \%$. The HT-29 cells were much less sensitive to the tested extract. Significant inhibition of DNA synthesis in HT-29 cells (11.2\% vs control) was observed only after the cells were treated with YGB INT at the highest tested concentration $(250 \mu \mathrm{g} / \mathrm{ml})$. YGB GW more effectively inhibited DNA synthesis in LS180 cells than YGB INT; nevertheless, the observed changes were not dose dependent. The antiproliferative effect observed in cells treated with the extract at concentrations of 16 and $315 \mu \mathrm{g} / \mathrm{ml}$ (17.1\% and $18.0 \%)$ was similar, and corresponded with results obtained after exposure of the cells to YGB INT at concentration $100 \mu \mathrm{g} / \mathrm{ml}$ (16.1\%). HT-29 cells were also more sensitive to YGB GW than YGB INT. BrdU test revealed significant dose-dependent inhibition of HT-29 cells proliferation after exposure to YGB GW. The pronounced effect was observed in cells treated with $32 \mu \mathrm{g} / \mathrm{ml} \mathrm{YGB} \mathrm{GW}$, which reduced BrdU incorporation to DNA to $85.9 \%$, which exceeds the range of changes reported after cells exposure to $250 \mu \mathrm{g} / \mathrm{ml}$ YGB INT (88.8\%). The strongest antiproliferative effect in HT-29 cells was observed after exposure of the cells to $2,100 \mu \mathrm{g} / \mathrm{ml} \mathrm{YGB} \mathrm{GW}$, which inhibited DNA synthesis by $51.6 \%$, compared to control.

Induction of morphological changes on human colon epithelial cells and human colon cancer cells by barley extracts. Changes in morphology of CCD 841 CoN, LS180 


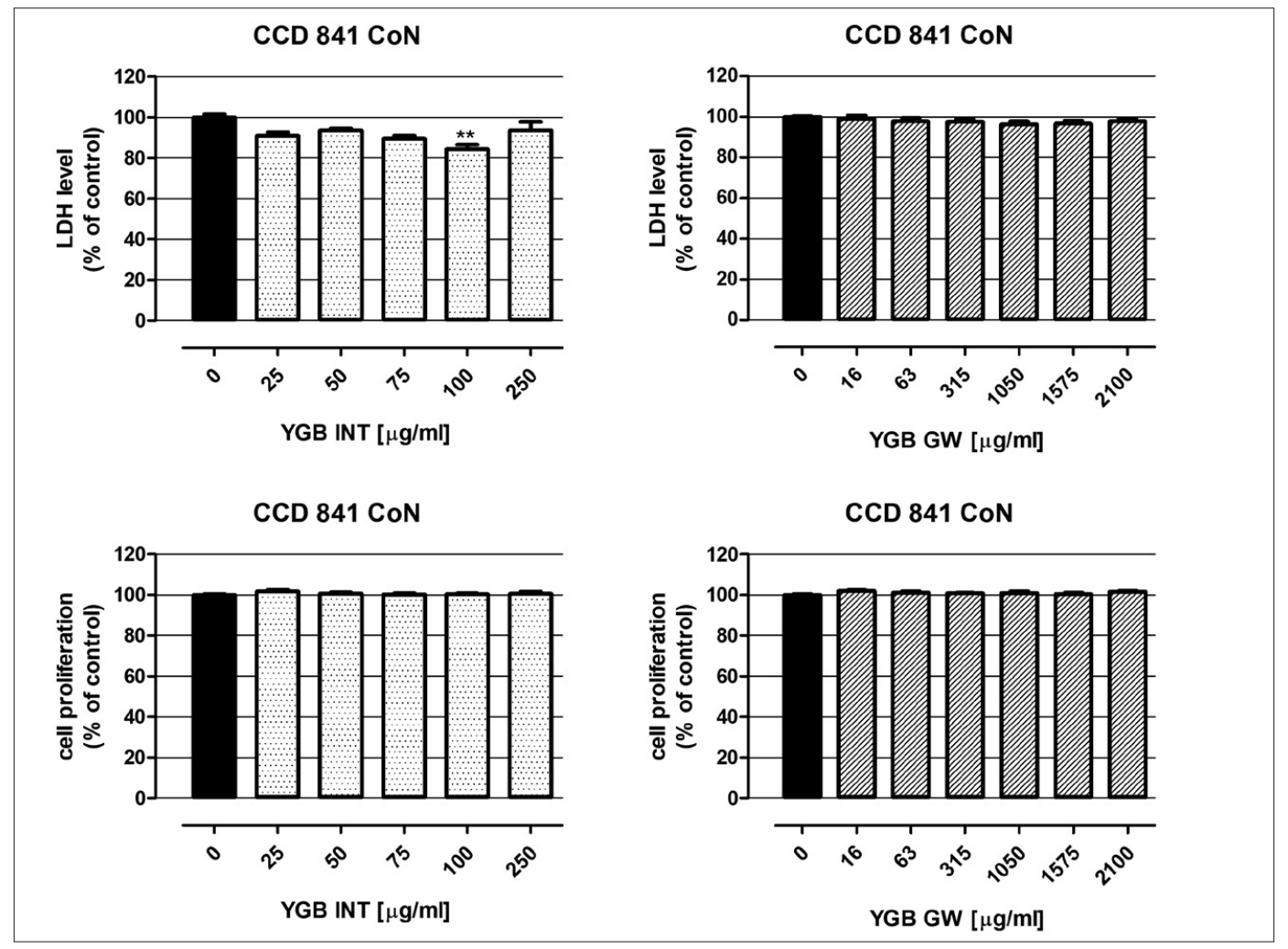

Figure 2. Impact of YGB INT and YGB GW extracts on human colon epithelium cell line CCD 841 CoN viability and proliferation. Cells were exposed to culture medium alone (control) or extracts in concentrations ranging from $25-250 \mu \mathrm{g} / \mathrm{ml} \mathrm{YGB} \mathrm{INT}-16-2100 \mu \mathrm{g} / \mathrm{ml} \mathrm{YGB} \mathrm{GW} \mathrm{for}$ $24 \mathrm{~h}$. Extracts cytotoxicity was measured photometrically by LDH assay (upper panel). Cell proliferation was measured photometrically by MTT assay (lower panel). Results presented as mean \pm SEM of 5 measurements.

${ }^{*} \mathrm{p}<0.05$ vs. control; ${ }^{* *} \mathrm{p}<0.01$ vs. control, one-way ANOVA test; post test: Tukey.

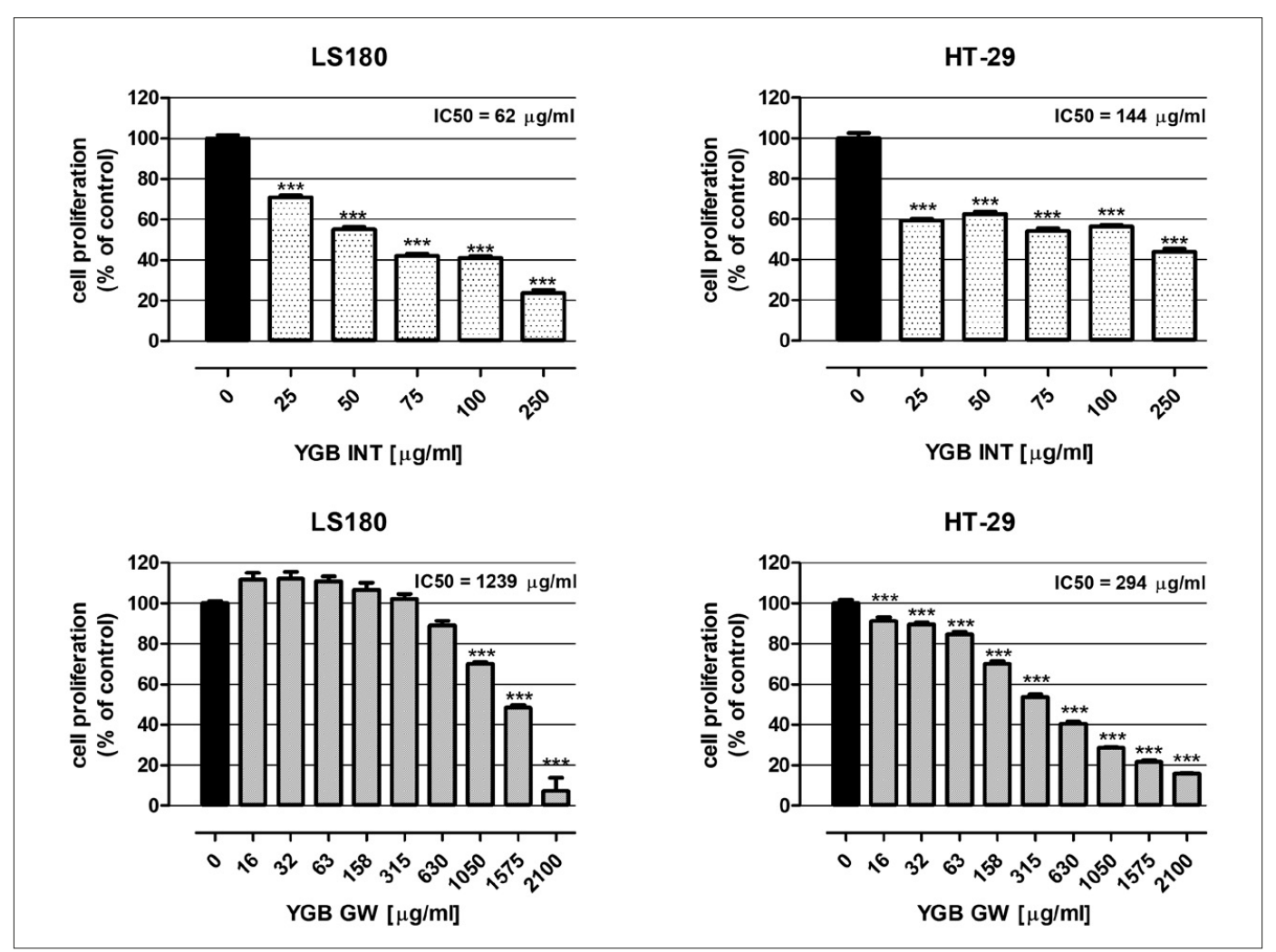

Figure 3. Antiproliferative effect of YGB INT and YGB GW extracts in human colon adenocarcinoma cell lines LS180 and HT-29. Cells were exposed to culture medium alone (control) or extracts in concentrations ranging from $25-250 \mu \mathrm{g} / \mathrm{ml} \mathrm{YGB} \mathrm{INT} \mathrm{-} \mathrm{16-2100} \mu \mathrm{g} / \mathrm{ml}$ YGB GW for $96 \mathrm{~h}$. Cell proliferation was measured photometrically by MTT assay. Results presented as mean \pm SEM of 6 measurements. ${ }^{*} \mathrm{p}<0.05$ vs. control; ** $\mathrm{p}<0.01$ vs. control; *** $\mathrm{p}<0.001$ vs. control, one-way ANOVA test; post test: Tukey. 


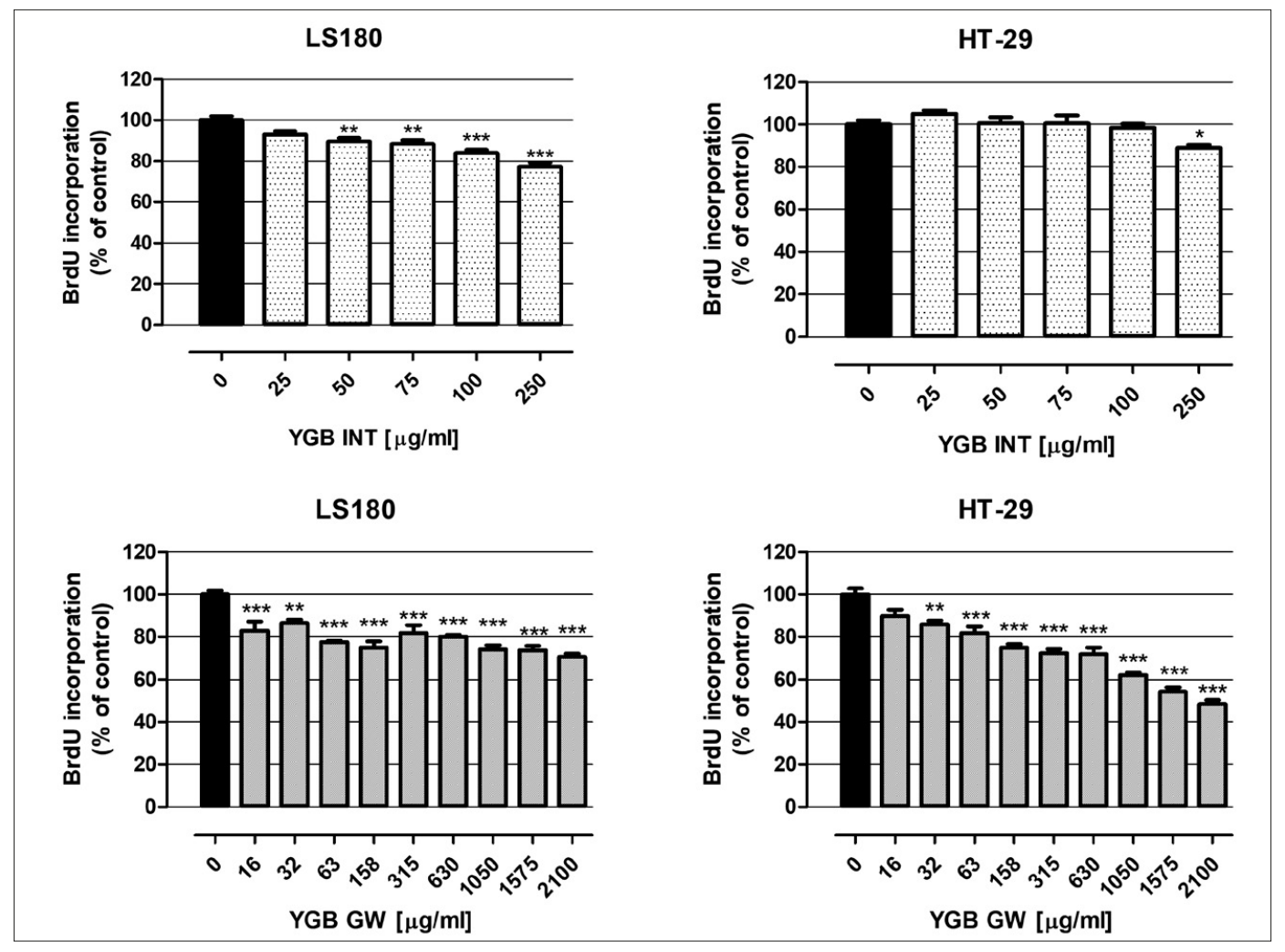

Figure 4. Antiproliferative effect of YGB INT and YGB GW extracts on human colon adenocarcinoma cell lines LS180 and HT-29. Cells were exposed to culture medium alone (control), or extracts in concentrations ranging from $25-250 \mu \mathrm{g} / \mathrm{ml} \mathrm{YGB} \mathrm{INT} \mathrm{-} \mathrm{16-2100} \mu \mathrm{g} / \mathrm{ml} \mathrm{YGB} \mathrm{GW}$ for $48 \mathrm{~h}$. Antiproliferative activity was assessed by BrdU assay. Results presented as mean \pm SEM of up to 6 measurements.

${ }^{*} p<0.05$ vs. control; ${ }^{* *} p<0.01$ vs. control; ${ }^{* * *} p<0.001$ vs. control, one-way ANOVA test; post test: Tukey.

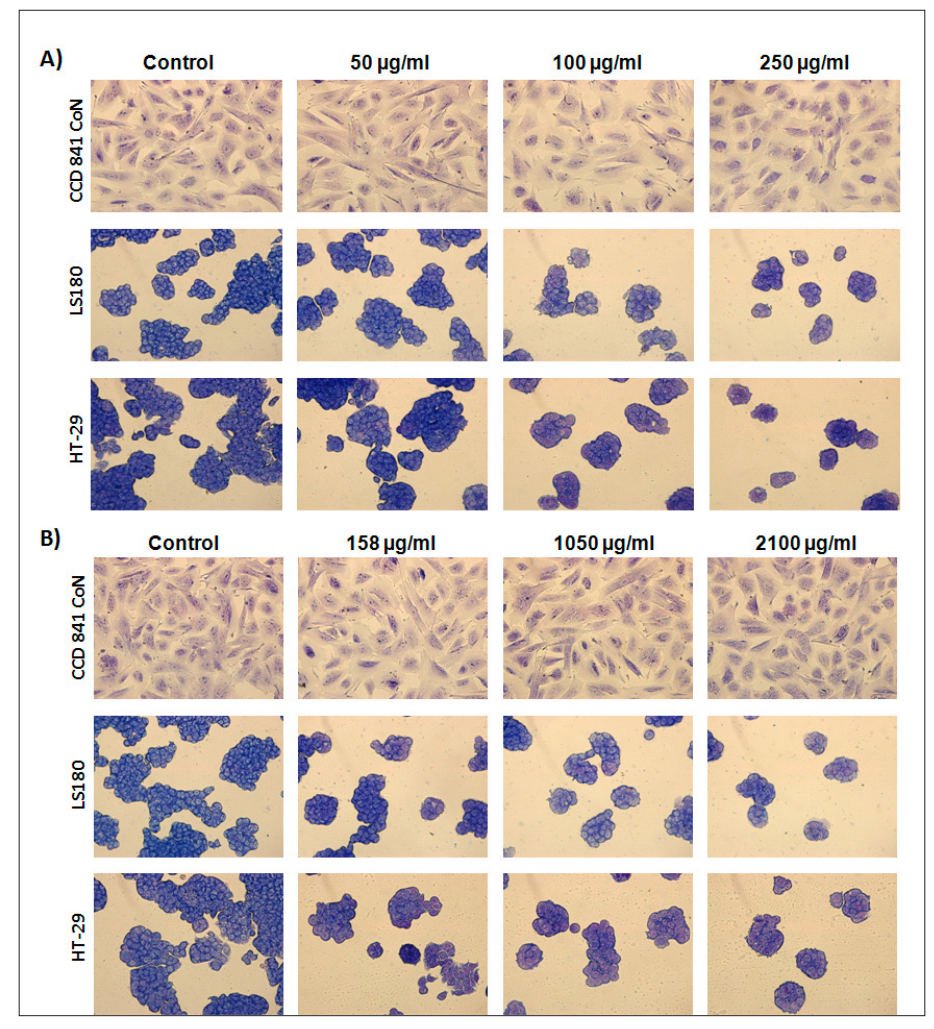

Figure 5. Impact of YGB INT and YGB GW extracts on morphology of human colon epithelial cell line CCD $841 \mathrm{CON}$, and human colon adenocarcinoma cell lines LS180 and HT-29. Cells were incubated for $48 \mathrm{~h}$ alone or in the presence of YGB INT (A) or YGB GW (B). Micrographs show normal morphology of investigated cells - control, and changes of cell morphology after $48 \mathrm{~h}$ exposure to YGB INT at concentrations 50, 100 and $250 \mathrm{ug} / \mathrm{ml}$ (A) and YGB GW at concentrations 158, 1050 and $2100 \mathrm{ug} / \mathrm{ml}$ (B). Magnification 400x. 
and HT-29 were investigated after 48 hours of cells treatment with barley extracts. After treatment, the cells were stained with May-Grünwald-Giemsa and induced alterations were visualized by light microscopy.

YGB INT did not affected morphology as well as growth pattern of colon epithelial cell line (Fig. 5A). At the same time, the tested extract inhibited proliferation of colon cancer cell lines LS180 and HT-29. Furthermore, YGB INT induced changes in the morphology of cancer cells. Cytoplasm swelling, disintegration of cell membranes and vacuolization were noticed and worsened in a dose-dependent manner.

YGB GW, similar to YGB INT, did not cause any negative changes in CCD841 CoN (Fig. 5B). On the contrary, the extract inhibited proliferation of LS180 and HT-29 cells and also induced changes typical for necrosis. Despite the fact that alterations in the morphology of colon cancer cells, induced by YGB GW, were similar to changes caused by YGB INT; nevertheless, both tested cell lines were less sensitive to this extract, and the observed effect was not dose dependent.

\section{DISCUSSION}

Young green barley is an important source of nutraceutical substances that can have an effect on biological functions to promote health and prevent disease, including cancer $[2,10$, 26]. These nutritional values favoured of its success. In recent years, young green barley and preparations based on it (juice, tea, tablets or dried grass) have gained enormous popularity among dietary supplements and phytopharmaceuticals. Despite the immense popularity, there are few reliable and solid scientific research on the influence of young barley on the human body. Amazingly, even less is known about its direct effect on both normal and cancer cells. Thuds, the presented study is one of the few attempts to extend this knowledge.

Cytotoxic studies revealed that both tested extracts did not affected the human epithelial cells (CCD841 CoN) viability, which corresponds with data presented by Czerwonka et al., which demonstrated that juice and young green barley water extract had a low cytotoxicity on CCD 841 CoTr (human colon epithelial cells) and HSF (human skin fibroblasts) [27]. Research conducted by Robles-Escajeda et al. also showed that aqueous green barley extract did not significantly affect the proliferation or viability of human foreskin fibroblasts (Hs27) [28]. Furthermore, in a whole range of investigated concentrations, the tested extracts did not affect colon epithelial cells proliferation.

The current study also revealed antiproliferative properties of the tested extracts in human colon cancer cell lines LS180 and HT-29, which corresponds with data obtained by Czerwonka et al. and Madhujith and Shahidi [27, 29]. As presented by Czerwonka et al., both water extract and juice obtained from young barley effectively inhibited HT-29 cells proliferation; nevertheless, their effectiveness - expressed as IC50 values - was worse than extracts tested in the current study, and amounted $0.7 \mathrm{mg} / \mathrm{ml}$ and $2.4 \mathrm{mg} / \mathrm{ml}$, respectively [27]. On the contrary, the studies conducted by Madhujith and Shahidi showed that aqueous methanolic extracts of whole kernels from 6 different barley cultivars significantly inhibited proliferation of human colorectal adenocarcinoma cell line Caco-2. Extracts inhibited cancer cells proliferation in the range of $29.3 \%-51.2 \%$ at $0.5 \mathrm{mg} / \mathrm{ml}$ and $9.3 \%-15.9 \%$ at $0.05 \mathrm{mg} / \mathrm{ml}$ after 96 hours of incubation [29].

All data cited above only suggest the possibility of using young barley extracts in the prevention and/or treatment of colon cancer. In this context, in vivo data provided by Kanauchi and Yao confirm the hypotheses [30,31]. Kanauchi et al. showed that germinated barley foodstuff prevented the development of azoxymethane-induced colon cancers in rats, by reduction in the number of aberrant crypt foci [31]. On the contrary, Yao et al. revealed that the aqueous extract of fermented barley (prepared from barley-shochu distillery by-product) with Lactobacillus plantarum dy-1, protect mice from colon cancer development induced by HT29 cells injection [30]. While discussing the antiproliferative properties of young barley extracts or products, it is also worth mentioning the research by Robles-Escajeda et al. They demonstrated that aqueous extract from barley leaves acts as effective inhibitors of divisions of human T-cell leukemia cells (Jurkat E6.1), human B-cell leukemia cells (NALM-6), and human Burkitt lymphoma B cells (BJAB) [28]. Interesting data was obtained by Meng et al., which revealed the ability of the methanol-soluble fraction from young barley leaves to decrease viability of murine melanoma cells (B16) through inhibition of melanin biosynthesis, which was correlated with the presence of tricin [32].

Both MTT and BrdU tests conducted in the presented study revealed the different sensitivity of colon cancer cells to the investigated extracts. HT-29 cells were more susceptible to YGB GW, while in case of YGB INT, a better response was noted in LS180 cells. Due to the varying degree of differentiation of tested cells lines and their genetic profile, the above-mentioned observation may be a harbinger of the different molecular mechanisms underlying the discovered antiproliferative activities of the tested extracts [33]. However, the presented study did not allowed confirmation or denial of this hypothesis. It also has to be noted that the results of MTT test indicated YGB INT as a better inhibitor of mitochondrial activity in colon cancer cells, while to the contrary, BrdU test revealed remarkable efficiency in inhibiting DNA synthesis by YGB GW. This indicates that YGB GW should be considered as a preferable antiproliferative agent.

May-Grünwald-Giemsa confirm both the non-toxic effect of the investigated extracts against human colon epithelial cells (CCD $841 \mathrm{CoN}$ ), and the antiproliferative effect in the case of human colon cancer cells (LS180 and HT-29). Next to the significant reduction in the number of colon cancer cells, the changes in their morphology, like disintegration of cell membranes, cytoplasm swelling and vacuolization, were also noted. These changes also suggest ability of the extracts to induce cancer cells necrosis, nevertheless, this observation requires confirmation by other specific investigations, especially in the light of data collected by Woo et al. and well as Yao et al. [30,34]. The former showed that barley grass extract induced apoptosis in human prostate cancer cells (DU 145) and human breast adenocarcinoma cells (MDA-MB-231) [34]. Proapoptotic properties of other products based on barley was also demonstrated by Yao et al., whose studies revealed that aqueous extract of fermented barley (prepared from barley-shochu distillery by-product) with Lactobacillus plantarum dy-1 could induce apoptosis in the subcutaneous transplantation of human HT-29 cells in nude mice [30]. It needs to be highlighted that despite the fact that the nature of the changes induced by the tested extract was similar, once 
again their effectiveness was different. Both colon cancer cell lines were more sensitive to YGB INT than to YGB GW.

The differences in the extracts antiproliferative and pronecrotic properties observed in colon cancer cell lines may be due to a few key differences in the extracts themselves. The most important seems to be the type of raw material. In GreenWays, leaves were the starting material, whereas in Intenson leaves and bladed of grass wewre used. The method of dealing with the collected raw material was also different. In GreenWays, the juice was squeezed out of the leaves and then subjected to a drying process. In the case of Intenson, the harvested barley grass was dried and then ground up. Consequently, 2 different products were created: dried juice (GreenWays) and ground, dried grass (Intenson).

The procedures for the preparation of the extracts used in this study also differed. The first major difference was the proportion between the amount of raw material and the solvent, and the solvent used in order to prepare YGB INT; $2.5 \mathrm{~g}$ of raw material was suspended in $100 \mathrm{ml}$ of water, in the case of YGB GW this proportion amounted to $3.3 \mathrm{~g}$ per $100 \mathrm{ml}$ of PBS. If the first stages of extract preparation, i.e. extraction, centrifugation and filtration, were similar, the method for dealing with the obtained filtrates was different. In the case of YGB GW, the resulting filtrate was the stock solution used i9n the current study. However, in the case of YGB INT, the collected filtrate was evaporated and the resulting crystals dissolved in PBS. It needs to be noted that the high temperature accompanying the drying of the barley grass and the evaporation could have inactivated some of the bioactive molecules (enzymes) and changed their concentration in the YGB INT extract. This may explain the worse antiproliferative activity. On the other hand, the greater efficiency of necrosis induction in colon cancer cells by YGB INT could have been caused by a much higher fibre content in the product, on the basis of which the extract was made (44\% compared $6.9 \%$ in the GreenWays product, according to the manufacturer's information).

\section{CONCLUSIONS}

The data obtained in the current study demonstrated that both young green barley extracts specifically inhibit proliferation of human colon cancer cells without any undesirable effect on human colon epithelial cells. Growth inhibition of cancer cells was closely associated with cell death induction by the tested extracts. Despite the very promising results, further studies are required to explain the molecular and cellular mechanisms of barley activity, the amount of consumption, possible adverse effects, and ideal methods of preparation. Additionally, identification and examination of the bioactive compounds present in barley extracts, responsible for the discovered anticancer properties, is also needed.

\section{REFERENCES}

1. Grando S, Macpherson HG. Food Barley: importance, uses and local knowledge. ICARDA, Aleppo, Syria. 2005. p. v, ix.

2. Prasad R, Prasad LC, Bornare SS. Barley crops (Model species), its use as food, feed, medicines and performed better when climatic conditions are unfavorable. Ind J Crop Ecol. 2014; 2(2): 47-52.

3. Blake T, Blake V, Bowman J, Abdel-Haleem H. Barley feed uses and quality improvement. In: Ullrich SE. Barley: Production, Improvement and Uses. Wiley-Blackwell. 2011; p. 522-531.
4. Nevo E, Fu YB, Pavlicek T, Khalifa S, Tavasi M, Beiles A. Evolution of wild cereals during 28 years of global warming in Israel. Proc Natl Acad Sci USA. 2012; 109(9): 3412-3415.

5. Kubota K, Sunagane N. Studies on the effects of green barley juice on the endurance and motor activity in mice. Paper presented at The 104th Annual Congress of The Pharmaceutical Society of Japan in Sendai City, Japan 1984.

6. Kubota K, Matsuoka Y, Seki H. Isolation of potent anti-inflammatory protein from barley leaves. Jap J Inflam. 1983; 3(4).

7. Yang J, Zeng Y, Yang X, Pu X, Du J. Utilization of barley functional foods for preventing chronic diseases in China. J Agric Sci Technol. 2016; 17(9): 2195-2204.

8. Brezinová Belcredi N, Ehrenbergerová J, Fiedlerová V, Běláková S, Vaculová K. Antioxidant vitamins in barley green biomass. J Agric Food Chem. 2010; 58(22): 11755-11761.

9. Paulickova I, Ehrenbergerová J, Fiedlerova V, Gabrovská D, Havlová P, Holasová M, et al. Evaluation of barley grass as a potential source of some nutritional substances. Czech J Food Sci. 2007; 25(2): 65-72.

10. Hagiwara Y, Cichoke A. Barley leaves extract for everlasting health. Green Food Corporation (USA 1998) and Japan Pharmaceutical Development (Osaka 1998).

11. Droushiotis D. The effect of variety and harvesting stage on forage production of barley in low rainfall environments. J Agr Sci. 1984; 102(2): 289-293.

12. Lee SH, Jew SS, Chang PS, Hong IJ, Hwang ES, Kim KS, et al. Free radical scavenging effect and antioxidant activities of barley leaves. Food Sci Biotechnol. 2003; 12(3): 268-273.

13. Cremer L, Herold A, Avram D, Szegli G. A purified green barley extract with modulatory properties upon TNF alpha and ROS released by human specialized cells isolated from RA patients. Roum Arch Microbiol Immunol. 1998; 57(3-4): 231-42.

14. Yamaura K, Tanaka R, Yuanyuan Bi, Fukata H, Oishi N, Sato H, et al. Protective effect of young green barley leaf (Hordeum vulgare L.) on restraint stress-induced decrease in hippocampal brain-derived neurotrophic factor in mice. Pharmacogn Mag. 2015; 11(1): S86-S92.

15. Takano A, Kamiya T, Tomozawa H, Ueno S, Tsubata M, Ikeguchi M, et al. Insoluble fiber in young barley leaf suppresses the increment of postprandial blood glucose level by increasing the digesta viscosity. Evid Based Complement Alternat Med. 2013; 2013: 137871.

16. Venugopal S, Iyer UM. Management of diabetic dyslipidemia with subatmospheric dehydrated barley grass powder. Int J Green Pharm. 2010; 4(4): 251-256.

17. Yu YM, Chang WC, Liu CS, Tsai CM. Effect of young barley leaf extract and adlay on plasma lipids and LDL oxidation in hyperlipidemic smokers. Biol Pharm Bull. 2004; 27(6): 802-805.

18. Yu YM, Chang WC, Chang CT, Hsieh CL, Tsai CE. Effects of young barley leaf extract and antioxidative vitamins on LDL oxidation and free radical scavenging activities in type 2 diabetes. Diabetes Metab. 2002; 28(2): 107-114.

19. Yu YM, Wu CH, Tseng YH, Tsai CE, Chang WC. Antioxidative and hypolipidemic effects of barley leaf essence in a rabbit model of atherosclerosis. Japan J Pharmacol. 2002; 89(2): 142-148.

20. Ohtake H, Nonaka S, Sawada Y, Hagiwara Y, Hagiwara H, Kubota K. Studies on the constituents of green juice from young barley leaves. Effect on dietarily induced hypercholesterolemia in rats. Yakugaku Zasshi. 1985; 105(11): 1052-1057.

21. Choi SW, Kim SH, Lee KS, Kang HJ, Lee MJ, Park KI, et al. Barley seedling extracts inhibit RANKL-induced differentiation, fusion, and maturation of osteoclasts in the early-to-late stages of osteoclastogenesis. Evid Based Complement Alternat Med. 2017; 2017: 6072573.

22. Kamiyama M, Shibamoto T. Flavonoids with potent antioxidant activity found in young green barley leaves. J Agric Food Chem. 2012; 60(25): 6260-6267.

23. Nunes LM, Robles-Escajeda E, Santiago-Vazquez Y, Ortega NM, Lema $\mathrm{C}$, Muro A, et al. The gender of cell lines matters when screening for novel anti-cancer drugs. AAPS J. 2014; 16(4): 872-4.

24. Pollitzer E. Biology: Cell sex matters. Nature. 2013; 500: 23-4.

25. Litchfield JT, Wilcoxon FA. A simplified method of evaluating doseeffect experiments. J Pharmacol Ex. Ther. 1949; 96: 99-113.

26. Kawka K, Lemieszek MK, Rzeski W. Prozdrowotne właściwości młodego jęczmienia. Med Og Nauk Zdr. 2017; 23(1): 7-12.

27. Czerwonka A, Kawka K, Cykier K, Lemieszek MK, Rzeski W. Evaluation of anticancer activity of water and juice extracts of young Hordeum vulgare in human cancer cell lines HT-29 and A549. Ann Agric Environ Med. 2017; 24(2): 345-349.

28. Robles-Escajeda E, Lerma D, Nyakeriga AM, Ross JA, Kirken RA, Aguilera RJ, et al. Searching in mother nature for anti-cancer activity: 
antiproliferative and pro-apoptotic effect elicited by green barley on leukemia/lymphoma cells. PLoS One. 2013; 8(9): e73508.

29. Madhujith T, Shahidi F. Antioxidative and antiproliferative properties of selected barley (Hordeum vulgarae L.) cultivars and their potential for inhibition of low-density lipoprotein (LDL) cholesterol oxidation. J Agric Food Chem. 2007; Jun 27; 55(13): 5018-24.

30. Yao F, Zhang JY, Xiao X, Dong Y, Zhou XH. Antitumor activities and apoptosis-regulated mechanisms of fermented barley extract in the transplantation tumor model of human HT-29 cells in nude mice. Biomed Environ Sci. 2017; Jan; 30(1): 10-21.

31. Kanauchi O, Mitsuyama K, Andoh A, Iwanaga T. Modulation of intestinal environment by prebiotic germinated barley foodstuff prevents chemo-induced colonic carcinogenesis in rats. Oncol Rep. 2008; 20(4): 793-801.

32. Meng TX, Irino N, Kondo R. Melanin biosynthesis inhibitory activity of a compound isolated from young green barley (Hordeum vulgare L.) in B16 melanoma cells. J Nat Med. 2015; 69(3): 427-431.

33. Lemieszek MK, Ribeiro M, Alves HG, Marques G, Nunes FM, Rzeski W. Boletus edulis ribonucleic acid - a potent apoptosis inducer in human colon adenocarcinoma cells. Food and Function. 2016; 7(7): 3163-3175.

34. Woo SM, Kwon SC, Ko SG, Cho SG. Barley grass extract causes apoptosis of cancer cells by increasing intracellular reactive oxygen species production. Biomed Rep. 2017; 6(6): 681-685. 